\title{
„Poznańskie Spotkania Językoznawcze”, t. 27: Przestrzenie jezykoznawstwa. Prace dedykowane Profesor Irenie Sarnowskiej-Giefing, red. Magdalena Graf, Wydawnictwo Poznańskiego Towarzystwa Przyjaciół Nauk, Poznań 2014, ss. 219
}

Zbiór artykułów naukowych zatytułowany Przestrzenie językoznawstwa. Prace dedykowane Profesor Irenie Sarnowskiej-Giefing powstał z okazji jubileuszu Pani Profesor i ukazał się w ramach czasopisma „Poznańskie Spotkania Językoznawcze". Poszczególne opracowania stworzyli przyjaciele, mistrzowie oraz podopieczni Jubilatki. Tematyka obejmuje zagadnienia onomastyki i glottodydaktyki. Każdy z Autorów napisał tekst, w którym połączył pasje badawcze Jubilatki z własnymi, co zaowocowało powstaniem zbioru wartościowego zarówno pod względem merytorycznym, jak i metodologicznym.

Publikację otwierają dwa teksty poświęcone osobie Pani Profesor oraz jej dotychczasowym dokonaniom. Napisane kolejno przez Karola Zierhoffera i Aleksandrę Cieślikową, pełnią funkcję rozbudowanych dedykacji, mających na celu zaprezentowanie sylwetki Pani Profesor oraz podkreślenie jej zasług i niesłabnącego wpływu na naukę i dydaktykę. Wprowadzają także odbiorcę w tematykę wszystkich opracowań.

W dalszej części publikacji czytelnik może zapoznać się z artykułami naukowymi, z których pierwszy zatytułowany Synkretyzm antroponimii Podlasia wyszedł spod pióra Zofii Abramowicz. Autorka zaznacza, że różnorodność nazewnictwa na opisywanych terenach wynika przede wszystkim z panującego tam synkretyzmu kulturowego. Koegzystencja i symbioza osób posługujących się różnymi językami oraz wyznających różne religie zaowocowała różnorodnością nazewnictwa, które stanowi efekt połączenia kilku języków i kultur. Wspomniana koegzystencja niejako wymusiła wypracowanie grupy wspólnych nazw niezależnie od przynależności etnicznej i kulturowej. W tekście czytelnik może zetknąć się z imionami oraz nazwiskami typowymi tylko dla tego regionu. 
Mieczysław Balowski w artykule Akvizice češtiny a propriálni sféra jazyka podejmuje tematykę glottodydaktyki języka czeskiego. Autor analizuje dwa podręczniki na poziomie A1, skupiając się przede wszystkim na nazwach własnych oraz ich funkcjach: informującej, komunikacyjnej, gramatycznej oraz socjo-kulturowej. Opracowanie przedstawia typy antroponimów, toponimów oraz chrematonimów wraz z pełnionymi przez nie funkcjami, tym samym prezentując, jaką informację przekazują poszczególne nazwy własne.

Edward Bereza w swoim tekście pt. Imiona pochodzace od nazw geograficznych skupia się na imionach derywowanych od nazw geograficznych: krajów, miast, wiosek, rzek oraz gór. Spis analizowanych antroponimów został zaczerpnięty ze Słownika imion wspótcześnie w Polsce używanych wydanego przez Kaimierza Rymuta w 1995 roku. Wynotowane imiona mają bardzo niską frekwencję i odnoszą się do cudzoziemców z polskim obywatelstwem. Wiele z tych imion straciło swoją podstawową motywację i obecnie przypisuje się im inną podstawę. Dotyczy to np. imienia Salwador, które można kojarzyć z łacińskim wyrazem Salwator, -oris oznaczającym Zbawiciela.

Artur Gałkowski w artykule Motywacja w procesie tworzenia chrematonimii marketingowej zaznacza, że funkcja tego typu nazw przenosi się na schemat wypowiedzi reklamowej, a w konsekwencji chrematonim jest podstawowym elementem komunikacyjnym w odniesieniu do obiektu. Czasami mówi się nawet o minimalnym komunikacie reklamowym, bo nazwa nie tylko stanowi element reklamy, ale także sama w sobie może być reklamą. Autor wyróżnia motywację: konceptualną, intraonomastyczną, asocjacyjno-konotacyjną, formalno-kreacyjną i kulturową, którą uważa za nadrzędną.

Tadeusz Lewaszkiewicz w opracowaniu Między idea wspólnego języka stowiańskiego i słowiańskimi mikrojęzykami literackimi podkreśla, że mikrojęzyki literackie wzbogacają słowiańską kulturę, podtrzymują tożsamość narodową i etniczną użytkowników oraz zapobiegają ich asymilacji. Kolejne próby wprowadzenia wspólnego makrojęzyka, nazywanego „esperantem słowiańskim” kończyły się porażką. Różnorodność języków Słowian potwierdza fakt, że obecnie istnieje ponad 20 tzw. słowiańskich mikrojęzyków literackich lub języków w trakcie kodyfikacji.

W pracy Określenia beneficjentów Kościoła katolickiego w szesnastowiecznej polszczyźnie Jolanta Migdał na podstawie analizy onimów występujących w Słowniku polszczyzny XVI wieku wnioskuje, że nazwy kościelnych beneficjentów powstałe w tamtym okresie zachowały się w polszczyźnie ogólnej lub odmianie kościelnej. Leksemy te przetrwały do dzisiaj nawet wtedy, gdy nazywany urząd bądź stanowisko przestały istnieć, co świadczy o silnie zakorzenionej w języku tradycji kościelnego nazewnictwa. 
Anna Piotrowicz i Małgorzata Witaszek-Samborska, Autorki tekstu Wokót potocznych poznańskich onimów Pomnik, Adaś i Krzyże, opisały, jak zmienia się urbanonimia miejska. Ankiety przeprowadzone wśród mieszkańców w różnym wieku wykazały, że potoczna onimia miasta zajmuje istotne miejsce w codziennej komunikacji, zaś tworzone przez poznaniaków nazwy (w przeciwieństwie do nazw urzędowych) cechują się motywacją znaczeniową.

Elżbieta Rudnicka-Fira opracowała tekst Imię i nazwisko Jubilatki w przestrzeni historyczno-kulturowej igeograficznej. Przeprowadzone na jego potrzeby analizy wskazują, że imię Pani Profesor było najczęściej nadawane w latach 20.-50. XX wieku; później nastąpiła wyraźna tendencja spadkowa. Pierwszy człon nazwiska - Sarnowska - dominuje w Polsce północnej i zachodniej, a drugi - Giefing - z powodu obcego pochodzenia wykazuje minimalną frekwencję na terenie naszego kraju. Według portalu Moi krewni w Polsce żyje obecnie tylko dziewięć osób noszących to nazwisko.

Autorki tekstu Od niemowy do człowieka dwujęzycznego, czyli o świadomości i nauczaniu języka polskiego gluchych - uwagi nie tylko glottodydaktyczne, Karolina Ruta i Marta Wrześniewska-Pietrzak, przedstawiły, jakie problemy z nauką języka polskiego mogą mieć osoby niesłyszące. W celu poprawy jakości ich życia oraz ułatwienia im nauki języka polskiego konieczna jest zmiana podejścia do osób niesłyszących oraz zaakceptowanie faktu, że foniczny język polski nie jest ich językiem naturalnym. Osoby niesłyszące należy zatem traktować jak obcokrajowców, którzy na co dzień używają języka wizualnego zamiast fonicznego. Jednocześnie osoby niesłyszące powinny zaakceptować konieczność opanowania języka obcego, jakim jest dla nich język polski w wariancie fonicznym. Tylko takie dwukierunkowe działanie pozwoli na usprawnienie edukacji osób niesłyszących, poprawę ich pozycji społecznej oraz przełamanie opozycji słyszący - niesłyszący.

Kolejny tekst, zatytułowany Moda w zakresie morfologii wspótczesnych emporionimów, napisała Małgorzata Rutkiewicz-Hanczewska. Badaczka opisuje $\mathrm{w}$ nim nie tylko zjawiska transonimizacji oraz onimizacji, ale również morfologiczne sposoby tworzenia nazw obiektów handlowo-usługowych. Współcześnie modne stały się neologizmy oraz emporionimy nawiązujące do znanych nazw, w których wspomniany związek można łatwo zauważyć, np. Szmatrix - Matrix. Nazwy własne mają wpływ na stosunek do nazywanego obiektu lub produktu, więc ich autorzy przywiązują dużą wagę do sposobu nazywania, a zwłaszcza do źródła motywacji.

Małgorzata Rybka oraz Jolanta Sławek w opracowaniu ,Imię Twoje (...) im bardziej puste, tym bliższe prawdy”. O nie-nazywaniu Boga w poezji Zbigniewa Jankowskiego opisały językowy obraz Stwórcy, wskazując na jego 
niejednorodność, złożoność oraz zmienność. Niezależnie od tego, czy poeta przyjmuje, czy odrzuca tradycję judeo-chrześcijańską, w utworach zwraca uwagę fakt, że Stwórca jest stale obecny w życiu człowieka, który stopniowo nawiązuje z nim bliższą relację. Ulegający transformacji sposób postrzegania Boga oddaje system wyznawanych przez poetę wartości.

Andrzej Sieradzki w artykule zatytułowanym Derywowane nazwiska odzawodowe w dokumentach poznańskich od XVI do XVIII wieku zaobserwował, że najczęściej występujące w nazwiskach odzawodowych formanty to -czyk, -ski, rzadziej -ik/-yk oraz -ek. W XVIII wieku w antroponimii Poznania można zauważyć spadek frekwencji nazw z bazowym - $k$ - zastąpionym wówczas przez formant $-s k i$, natomiast różne formanty pełniły tę samą funkcję w tworzeniu nazwisk odzawodowych.

Nazwiskom poznaniaków poświęciła swój artykuł także Wanda Szulowska, która w tekście Nazwiska z sufiksem -(ow)ic(z)/-(ew)ic(z) w parafii św. Wojciecha w Poznaniu (XVII-XVIII wiek) wskazuje, że analizowane nazwiska nie są typowo mieszczańskie. W XVII i XVIII wieku na znacznym obszarze Polski sufiks -owicz/-ewicz utracił swoją pierwotną funkcję patronimiczną na rzecz strukturalnej, polegającej na dziedziczeniu bez zmiany nazwiska z tym formantem oraz tworzeniu antroponimu odbiegającego od apelatywnej podstawy lub nazwy zawodu.

Bogdan Walczak w artykule Trzy refleksje o dwujęzyczności opisuje wnioski nasuwające się w związku z rozważaniami kwestii bi- oraz multilingwizmu. Jednym z nich jest fakt, że dwu- oraz wielojęzyczność są obecnie bardziej powszechne niż jednojęzyczność, zatem badania komunikacji językowej powinny uwzględniać rozmiar tego zjawiska. Kolejna refleksja dotyczy tezy o fundamentalnej roli dwujęzyczności w glottodydaktyce. Autor skupia się też na zaprezentowaniu roli dwu- oraz wielojęzyczności w językoznawstwie.

Opracowanie Marioli Walczak-Mikołajczakowej Kilka uwag o imionach rodopskich Pomaków prezentuje imiona bułgarskojęzycznych muzułmanów, którzy w wiekach XV-XIX przeszli na islam. Ze względu na wieloletnie działania asymilacyjne członkowie społeczności Pomaków sami niejednoznacznie postrzegają własną tożsamość, a wielokrotne zmiany muzułmańskich imion i nazwisk doprowadziły do pogłębienia wspomnianego dysonansu. Autorka artykułu skupia się przede wszystkim na zaprezentowaniu przyczyn oraz konsekwencji częstych zmian antroponimów określających Pomaków zamieszkujących Rodopy.

Recenzowany tom zamyka artykuł Ewy Wolnicz-Pawłowskiej zatytułowany Nazwy własne w przekładzie. Zarys problematyki, w którym Badaczka przedstawia specyfikę nazw własnych oraz dawne i obecne sposoby włączania 
ich do języka polskiego. Wśród metod wyróżnia: adaptacje, adideacje i reinterpretacje oraz tłumaczenia, zaznaczając jednocześnie, że współcześnie adaptacja jest raczej powierzchniowa, a nazwy coraz częściej występują w pierwotnej postaci.

Na końcu publikacji zamieszczono biogramy wszystkich Autorów, którzy przyczynili się do powstania tego tomu.

Opracowanie Przestrzenie językoznawstwa. Prace dedykowane Profesor Irenie Sarnowskiej-Giefing, niezależnie od celu powstania, jakim jest uczczenie jubileuszu Pani Profesor Ireny Sarnowskiej-Giefing, w całości cechuje się walorami poznawczymi i dydaktycznymi. Z powodzeniem może służyć wszystkim czytelnikom zainteresowanym problematyką onomastyki oraz glottodydaktyki, niezależnie od tego, czy są studentami, czy doświadczonymi badaczami języka.

Marta Nowak 
